\title{
SPECIAL ISSUE: Anglicisms in Domain-Specific Discourse: Fashion, Leisure and Entertainment
}

\author{
Carmen Luján García ${ }^{1}$ \\ Universidad de Las Palmas de Gran Canaria \\ Virginia Pulcini ${ }^{2}$ \\ Università degli Studi di Torino
}

Current facts such as globalized markets and internationalization have led to the increasing spread of the English language as the main vehicle of cross-border communication, especially among speakers whose native language is not English. This role of English as a lingua franca of international communication in multilingual contexts has been studied and differently assessed by scholars, who have envisaged, on the one hand, a useful improvement of global understanding by means of a shared code (Seidlhofer, 2011) or, on the other hand, a dangerous reduction of the world's linguistic diversity (Phillipson, 2008).

The different contexts in which English is used today on a global scale can hardly be categorized without making gross simplifications, as aptly explained by Onysko (2016). Several decades ago, the 'Three Circles Model of World Englishes' proposed by Braj Kachru (1992) offered a clear geopolitical tripartite distinction between ENL, ESL and EFL countries and food for speculation into nativization, language norms

$1 \quad$ Corresponding author: Universidad de Las Palmas de Gran Canaria, Departamento de Filología Moderna, Campus de Tafira, Edificio de Ingenierías, módulo F, despacho 1, 35100 Las Palmas de Gran Canaria (España).

Email: carmen.lujan@ulpgc.es

2 Università degli Studi di Torino, Dipartimento di Lingue e Letterature Straniere e Culture Moderne, Via Verdi 10, 10124 Torino (Italy).

Email: virginia.pulcini@unito.it 
(standard vs non-standard) and the notion of 'native speaker' for the upcoming debate on world Englishes. At present, the situation of the English-speaking world appears extremely complex, even just limiting the focus to the expanding circle of 'norm-dependent' EFL users, to which European countries are considered to belong. In the Nordic countries, speakers are exposed to English from an early age through education and the mass media, and therefore become very proficient users of English. These countries are said to be moving from EFL to ESL status, according to Kachru's model. By contrast, in other parts of Europe (e.g. in Mediterranean countries) exposure to English outside the school environment is still quite limited (Campagna \& Pulcini, 2014); moreover, other 'big languages' like French, German and Russian are used for international trade and commerce, apart from English, and the defense of multilingualism is an undisputed European principle. In sum, the current primacy of the English language in Europe is set in a diverse sociolinguistic context and challenged by the strength of national languages and by a marked sense of identity of the different speech communities.

The linguistic and cultural influence of Anglophone countries has been noteworthy at least from the $18^{\text {th }}$ century in Europe, when Britain, which was the leading nation of the industrial revolution, started being a donor of vocabulary in many technical fields (e.g. transport, industry) and offered a model of social and cultural progress (e.g. politics, fashion and sport). Since the $20^{\text {th }}$ century the USA has taken the lead in the global economy, politics and military intervention, strengthening the role of English as a donor language also in many areas of society and mass culture, like music, advertising, cinema, information technology, the Internet and the social media. The leadership of Anglophone countries has given rise to a widespread 'Anglicization' of European lexis (Pulcini, Furiassi \& Rodríguez González, 2012), i.e. the importation and assimilation of English words in the vocabularies of European languages. This lexical impact amounts to several thousands of English borrowings, which are taken as direct loanwords (adapted and non-adapted), or remodeled into the recipient languages through translation (calques) and domestic items (semantic loans) or English-inspired loose equivalents, hybrid creations, and pseudo-loans (Furiassi, 2010; Furiassi \& Gottlieb, 2015; Pulcini, Furiassi \& Rodríguez González, 2012).

Nowadays, no matter the area in which you work, people are exposed to many English words through the media, printed and audio-visual advertisements (GarcíaMorales, González Cruz, Luján García \& Rodríguez Medina, 2016). Europeans have assimilated social habits such as the consumption of fast food and its related products (e.g. burgers, nuggets, chips), and youngsters wear clothes like T-shirts and caps that display English (or pseudo-English) messages. The exposure to English in 
our daily life is such that people unconsciously take it for granted. In Spain, LujánGarcía (2013) has reported on the influence that English is exerting on the Spanish language and culture, and Balteiro (2011) has contributed to the description of the impact of English on domain-specific discourse. In the recently published Gran Diccionario de Anglicismos (2017), Rodríguez-González has recorded more than 4,500 Anglicisms, testifying to the high number of words that are attested in the Spanish language. The penetration of English in the vocabularies of other European languages has been thoroughly investigated by research on individual languages and dictionaries of Anglicisms (see complete list in Pulcini, Furiassi \& Rodríguez González, 2012, p. 23-24). From a comparative perspective of English-induced lexical borrowing among sixteen European languages, the pioneering contribution of Manfred Görlach (2001, 2002a, 2002b) has paved the way for research into the linguistic outcomes of the Anglicization of European lexis. This field of research has spread across the globe in such a way that a network of scholars (GLAD, i.e. Global Anglicism Database) interested in the influence of English on other languages (European and non-European) was constituted in 2016, with the aim of establishing cooperation among scholars interested in Anglicisms, promoting research and assessing the influence of English in world languages through the making of an online database of Anglicisms. ${ }^{3}$ The languages represented so far in this encompassing project are Bulgarian, Cantonese, Catalan, Czech, Danish, Dutch, French, Galician, German, Greek, Italian, Japanese, Norwegian, Polish and Spanish.

The domains of fashion, leisure and entertainment have been chosen for this Special Issue of LFE as they represent long-standing, productive and interesting areas of English-induced lexical borrowing. Quite a few studies have already explored the impact of English in these domains (for Spanish, Balteiro, 2011; Balteiro \& Campos, 2012; Díez-Arroyo, 2016; González-Cruz, 2016; Rodríguez-Medina, 2016; LujánGarcía, 2017; for Italian, Lopriore, 2007; Lopriore \& Furiassi, 2015). Although most fashion terminology comes from French, British fashion has greatly contributed to the enrichment of fashion vocabulary since the $19^{\text {th }}$ century, when terms like mackintosh (rainproof coat), smoking (a pseudo-Anglicism, denoting a 'dinner jacket'), and shorts were already in use. Also forms of leisure and entertainment - sport being the oldest and still the most productive area of English-induced lexical borrowing - were affected by English, starting from old card games like poker and bridge to modern forms of popular entertainment like television shows and videogames. Like many other fields, fashion, leisure and entertainment are

3 Interested readers who want to learn more about this project can visit https://www.gladnetwork.org 
characterized by a core of technical terminology, known by experts, like the field of textiles in fashion, and by a general vocabulary that is familiar to a non-specialist audience, even to people with limited competence in English.

The use of Anglicisms in these fields has a referential function in many cases, as there is no equivalent for the English term in the recipient languages, either because it is a newly created term in the US or the UK (e.g. leggings, sneakers, push-up) or because the Anglicism provides a neutral, international word that is worldwide known to refer to a specific referent (blue jeans). In addition, the terms encountered in fashion media language are loaded with an expressive value of style and modernity that the other languages do not seem to express. An example is the word 'cool', used informally to denote something 'fashionably attractive or impressive'." Even when the recipient language already has a word for expressing a particular meaning, the use of an Anglicism instead adds a touch of sophistication: in Spanish belleza enters in competition with beauty; celebrity or its abbreviated form celeb is often preferred to the domestic adjective famoso, which can be used as a short form of persona famosa; the same applies to the pairs fashion (Sp. moda), look (Sp. apariencia), makeup (Sp. maquillaje), top (Sp. camiseta corta), trendy (Sp. moderno).

The seven research articles presented in this Special Issue of LFE focus on aspects of the selected domains in some European languages, namely French, German, Greek, Italian, Polish, and Spanish.

In the article entitled "Non-pronominal uses of it: a case study in women fashion magazines", Isabel Balteiro opens the issue by exploring the field of fashion with the analysis of the non-pronominal uses of it to denote a person or a thing which is extremely fashionable. Drawing on a sample of over four million words from international fashion magazines published in Spanish, Balteiro identifies and describes the adjectival uses of it which may be either directly taken from English in short phrases or compounds like it girl, or adapted to Spanish linguistic contexts as in calzado it or más it. These uses of it are considered to be prestigious and trendy so that fashion followers are usually eager to accept these terms and even imitate such usage as they wish to sound 'professional' and 'cool'.

The article "Texas Hold'em Anglicisms in Italian”, presented by Paola Brusasco, deals with the world of gambling and in particular the variety of poker known as Texas Hold'em, and its terminology. She provides a cultural overview of the spread of this form of entertainment, which dates back to the early $20^{\text {th }}$ century in Italy and

4. https://en.oxforddictionaries.com/definition/cool 
has undergone a huge popularization with the boom of online gambling since the late 1990s. Although a limited number of English poker terms are registered in Italian dictionaries, their number is very high in official regulations, often accompanied by Italian translation equivalents. The growth of this peripheral area of vocabulary seems to have taken place beyond the control of mainstream Italian lexicography, rather as a specialized jargon of gambling circles and regular players.

The contribution offered by Sabine Fiedler, "Phraseological Anglicisms in German: A Look at a satirical TV program", addresses the use of phraseological Anglicized structures in the fields of media, journalism, advertising and entertainment in German. The author examines the use of English expressions and sentence-like units such as catchphrases, proverbs in a German satirical TV program heute-show. She reports that one third of the compiled corpus is composed of this kind of Anglicized constructions, being political slogans, titles of films and brand names particularly suitable for exploiting phraseological Anglicisms in a creative way. Expressions such as gin-tonic, happy end, fake news, no risk-no fun, big brother (is watching you) are some of the examples included in this paper.

The article written by Goretti García-Morales, "Anglicismos del cine como vehículo de estereotipos anglosajones", presents the impact of the English language and Anglo-American culture through the analysis of the cinema and the filmic area in Spanish. This author points out that film reviewers in Spain employ a remarkable number of Anglicisms in their reviews published in journals specialized in movies and the field of cinema. Thus, English loans such as biopic, buddy movie, cartoon, court room, criminal fiction, freak, ghost story, road movie, slasher, among others, are part of the jargon used by film experts when talking or writing about movies. García-Morales provides plenty of examples where the terms included in the compiled corpus demonstrate how this domain-specific language is highly influenced by the presence of Anglicisms.

The paper presented by Ramón Martí-Solano, “Le brunch et son réseau d'anglicismes: étude sur un corpus spécifique" deals with the use of the term brunch in French in a corpus compiled by the author for this purpose over the last five years. According to the author, the use of an Anglicism in a particular context attracts other English borrowings associated to the same semantic field. MartíSolano tracks the origin, evolution and current use of brunch and other English words such as cookies, pancake, cheesecake, muffin, bagel, cupcake, brownie, which are related to the domain of food and leisure, and have been introduced into French over the last few years, and compares his results with data extracted from the French press. 
The contribution of Alicja Witalisz, "Polish Anglicisms in the fields of leisure, fashion and entertainment against historical background", provides a historical overview of the evolution of over a thousand English borrowings in Polish in the semantic fields of leisure, fashion and entertainment. The items are collected from several lexicographic sources and cover the period from the $17^{\text {th }}$ century to the present, although the influence of English has been strong only since the late 20th century, when Poland began to freely access the cultural novelties of Western Europe and of the Unites States. The majority of borrowings are lexical loans such as eyeliner, outlet, fitness, whereas a lower number are loans translations (e.g. niski sezon < E. low season), semantic loans (e.g. nominacja < E. nomination) and loanblends (e.g. tenis stołowy $<$ E. table tennis).

In "Fashion Anglicisms in Modern Greek: A preliminary investigation", George Xydopoulos and Rania Papadopoulou offer a preliminary account of the impact of English on the Greek fashion industry, examining lexical items collected from Internet web pages, online shops and fashion magazines as well as social media accounts. First, they identify the fields that are mostly affected by English borrowings, namely clothes (e.g. leggings), shoes (e.g. mules), lingerie (e.g. push-up), accessories (e.g. handbag), fabrics (e.g. denim), people (e.g. fashion icon) and styles (e.g. vintage). They also consider the word classes to which Anglicisms belong and present some phraseological patterns such as casual look and urban style, as well as loan translation and English-Modern Greek hybrid forms. The authors' preliminary conclusion is that online sources prefer to use non-transliterated Anglicisms rather than transliterated ones, the reason being, first of all, that English-looking Anglicisms add to the international identity of the multinational company (even when this is a Greek one) and secondly, that transliteration would make recently borrowed items less recognizable to the general public.

To conclude, this Special Issue provides fresh new data to research into the field of English-induced lexical borrowing in the language of fashion, leisure and entertainment in six selected European languages. Our goal is to provide inspiring ideas to encourage further investigation on the area of Anglicisms in Europe from a cross-linguistic perspective, in addition to raising awareness on the effects of globalization and the spread of English as a lingua franca. In years to come, as Pulcini (2017) forecasts, Europeans will witness whether the lexical influence of English will continue, or whether the Brexit referendum and the withdrawal of the United Kingdom from the European Union will mark a decline.

We would like to conclude this introduction by expressing our thanks, firstly, to the Revista de Lenguas para Fines Específicos for offering us the opportunity to edit this 
Special Issue and for providing scholars working in the field of English-induced lexical borrowing a forum to present their research on Anglicisms in the domains of fashion, leisure and entertainment. Finally, we are grateful to all the scholars who served as anonymous reviewers and provided insightful comments to improve and enrich the collection of papers presented here.

\section{References}

Balteiro, I. (2011). A Few Notes on the Vocabulary of Textiles and Fashion. In I. Balteiro (Ed.), New Approaches to Specialized English Lexicology and Lexicography (pp. 65-81). Newcastle upon Tyne: Cambridge Scholars Publishing.

Balteiro, I. \& Campos, A. M. (2012). False anglicisms in the Spanish language of fashion and beauty. Ibérica, 24, 233-260.

Campagna, S. \& Pulcini. V. (2014). English as a medium of instruction in Italian universities: linguistic policies, pedagogical implications. In M. Guido \& B. Seidlhofer (Eds.), Textus. English Studies in Italy. Perspectives on English as a Lingua Franca, XXVII(1), 173-190.

Díez-Arroyo, M.(2016). English words as euphemisms in Spanish fashion. English Today 127(32/3), 30-39.

Furiassi, C. (2010). False Anglicisms in Italian. Monza: Polimetrica International Scientific Publisher.

Furiassi, C. \& Gottlieb, H. (Eds) (2015). Pseudo-English: Studies on False Anglicisms in Europe. Boston \& Berlin: De Gruyter Mouton.

García-Morales, G., González Cruz, I., Luján García, C. \& Rodríguez Medina, Mª. (2016). La presencia del inglés en la publicidad televisiva española (2013-2015). Madrid: Síntesis.

González Cruz, M ${ }^{a}$ I. (2015). Anglicising leisure: The multimodal presence of English in Spanish TV adverts. Calidoscopio, 13(3), 339-352.

Görlach, M. (ed.) (2001). A Dictionary of European Anglicisms. Oxford: Oxford University Press.

Görlach, M. (2002a). English in Europe. Oxford: Oxford University Press.

Görlach, M. (2002b). An Annotated Bibliography of European Anglicisms. Oxford: Oxford University Press.

Jenkins, J. (2003). English as a Lingua Franca: Attitude and Identity. Oxford: Oxford University Press.

Kachru, B.B. (1992). The Other Tongue: English across Cultures. Illinois: University of Illinois Press. 
Lopriore, L. (2007). Fashion in city magazines: the global and the local in Time Out. In L. Jottini, G. Del Lungo \& J. Douthwaite (Eds.), Cityscapes: Islands of the Self, vol. 2 [Language Studies], (pp. 375-390). Cagliari: Cooperativa Universitaria Editrice Cagliaritana.

Lopriore, L. \& Furiassi, C. (2015). The influence of English and French on the Italian language of fashion: Focus on false Anglicisms and false Gallicisms. In C. Furiassi \& H. Gottlieb (Eds.), Pseudo-English: Studies on False Anglicisms in Europe (pp. 197-226). Boston \& Berlin: De Gruyter Mouton.

Luján-García, C. (2013). The English Language and the Anglo-American Culture: Its Impact on Spanish Language and Society. Newcastle upon Tyne: Cambridge Scholars Publishing.

Luján-García, C. (2017). Analysis of the Presence of Anglicisms in a Spanish Internet Forum: Some Terms from the Fields of Fashion, Beauty and Leisure. Revista Alicantina de Estudios Ingleses 30, 277-300.

Onysko, A. (2009). Exploring discourse on globalizing English: A case study of discourse on Anglicisms in German. English Today 97(25/1): 25-36. https://doi.org/10.1017/S026607 8409000054

Onysko, A. (2016). Modeling world Englishes from the perspective of language contact. World Englishes, 35(2), 196-220. doi: 10.1111/weng.12191

Phillipson, R. (2008.) Lingua franca or lingua frankensteinia? English in European integration and globalization. World Englishes 27(2), 250-267.

Pulcini, V. (2017). Anglicisms in Italian: Moving on into the third millennium. In C. Boggio \& A. Molino (Eds.) English in Italy: Linguistic, educational and professional challenges (pp. 13-35). Milano: FrancoAngeli.

Pulcini, V., Furiassi, C. \& Rodríguez González, F. (2012). The lexical influence of English on European languages: From words to phraseology. In C. Furiassi, V. Pulcini \& F. Rodríguez González (Eds.) The Anglicization of European Lexis (pp. 1-24). Amsterdam: John Benjamins.

Rodríguez González, F. (2017). Gran Diccionario de Anglicismos. Madrid: Arco Libros.

Rodríguez Medina, $\mathrm{M}^{\mathrm{a}}$ J.. (2016). The Use of Anglicisms in Spanish Television Commercials of Cosmetics, Hygiene and Personal Care Products. Hermes Journal of language and communication in business, 55, 157-169.

Rogerson-Revell, P. (2007). Using English for International Business: A European case study. English for Specific Purposes, 26, 103-120.

Seidlhofer, B. (2011). Conceptualizing English for a multilingual Europe. In A. De Houwer \& A. Wilton (Eds.) English in Europe Today. Sociocultural and Educational Perspectives (pp. 133-146). Amsterdam/Philadelphia: John Benjamins. 